\title{
TIME-KILL ASSAY: AN EFFICACY OF SYNERGY BETWEEN CARBAPENEMS AND CLODRONIC ACID
}

\author{
A.G. Afinogenova ${ }^{a, b}$, T.M. Voroshilova ${ }^{c}$, G.E. Afinogenov ${ }^{b}$, D.Yu. Maday, \\ A.A. Spiridonova ${ }^{d}$ \\ a St. Petersburg Pasteur Institute, St. Petersburg, Russian Federation \\ ${ }^{b}$ St. Petersburg State University, St. Petersburg, Russian Federation \\ ${ }^{c}$ Nikiforov Russian Center of Emergency and Radiation Medicine, St. Petersburg, Russian Federation \\ ${ }^{d}$ Pavlov First St. Petersburg State Medical University, St. Petersburg, Russian Federation
}

\begin{abstract}
Currently, a search for augmenting antibiotics activity is still crucial due to elevated frequency of detecting carbapenem-resistant Gran-positive bacterial isolates. To resolve this, it might be reasonable to combine carbapenems metal- $\beta$-lactamase $(\mathrm{M} \beta \mathrm{L})$ inhibitors. Unfortunately, no $\mathrm{M} \beta \mathrm{L}$ inhibitors approved for treatment of carbapenem-resistant infections are currently available. Pathogenic bacteria may survive antibiotic attack, exert tolerance and persistence accompanied with the ongoing infectious process. In connection with this, determining dependence between antimicrobialrelated bactericidal effect and exposure time on microbes at 4, 8, 12 and 24 hours after the onset, a so called time-kill assay, is necessary. A synergy between both agents was noted upon reduced microbial population by $\geq 3 \log _{10}$. A checkerboard array followed by seeding the microplate well contents onto a dense nutrient medium at various time points were used to assess a synergistic efficacy of carbapenems applied together with clodronic acid against MBL-producing VIMgenotype $P$. aeruginosa 532/14 clinical isolate obtained from patients with infectious complications (minimal inhibitory concentrations [MIC] for imipenem or meropenem were $512 \mu \mathrm{g} / \mathrm{ml}$ ), microbial burden $10^{6} \mathrm{CFU} / \mathrm{ml}$. Optical density was measured at two wavelengths $(490$ and $630 \mathrm{~nm}$ ) in ELx800 reader, within 4-24 hour exposure time to determine time of logarithmic growth phase emerging in test culture. It is noteworthy that magnitude of optical density is a difference between two bichromatic measurements resulting in remarkably reduced inaccuracy due to scratches or fingerprints left on the plate. It was found that clodronic acid exhibited a synergic bactericidal effect with carbapenems against a clinically resistant M $\beta$ L-producing VIM-genotype $P$. aeruginosa 532/14 strain. Upon that, imipenem-related antimicrobial activity was evident as early as 8 hours after the onset decreasing cell growth down to $1.4 \log _{10}$ compared to control, whereas 12 hours later it resulted in total inhibition of test strain by decreasing growth of the test strain by $6 \log _{10}$. Meropenem in combination with clodronic acid showed a more pronounced activity: complete absence of P. aeruginosa 532/14 growth by 8 hours of incubation, growth suppression by $3.2 \log _{10}$, which reached $6 \log _{10} 12-24$ hours after the onset. Time-kill assay allows to identify efficient combinations of carbapenems and $\mathrm{M} \beta \mathrm{L}$ inhibitors, which is of great importance for increasing therapeutic efficacy of patients with severe purulent-septic complications.
\end{abstract}

Key words: clodronic acid, carbapenem-resistant Gram-negative bacteria, metal- $\beta$-lactamase inhibitor, carbapenems, time-kill assay.

\section{Адрес для переписки: \\ Афиногенова Анна Геннадьевна \\ 197101, Россия, Санкт-Петербург, ул. Мира, 14, \\ ФБУН НИИ эпидемиологии и микробиологии имени Пастера. \\ Тел.: 8 (812) 232-86-31 (служебн.); 8921 557-88-94 (моб.). \\ E-mail: spbtestcenter@mail.ru}

\section{Библиографическое описание:}

Афиногенова А.Г., Ворошилова Т.М., Афиногенов Г.Е., Мадай Д.Ю.,

Спиридонова А.A. Time-kill assay: эффективность синергидного

действия карбапенемов и клодроновой кислоты // Инфекция

и иммунитет. 2018. Т. 8, № 4. С. 497-502. doi: 10.15789/2220-7619-2018-

4-497-502

() Afinogenova A.G. et al., 2018

\section{Contacts:}

Anna G. Afinogenova

197101, Russian Federation, St. Petersburg, Mira str., 14,

St. Petersburg Pasteur Institute.

Phone: +7 (812) 232-86-31 (office); +7 921 557-88-94 (mobile).

E-mail: spbtestcenter@mail.ru

\section{Citation:}

Afinogenova A.G., Voroshilova T.M., Afinogenov G.E., Maday D.Yu.,

Spiridonova A.A. Time-kill assay: an efficacy of synergy between carbapenems and clodronic acid // Russian Journal of Infection and Immunity = Infektsiya i immunitet, 2018, vol. 8, no. 4, pp. 497-502. doi: 10.15789/2220-7619-2018-4-497-502

DOI: http://dx.doi.org/10.15789/2220-7619-2018-4-497-502 


\title{
TIME-KILL ASSAY: ЭФФЕКТИВНОСТЬ СИНЕРГИДНОГО ДЕЙСТВИЯ КАРБАПЕНЕМОВ И КЛОДРОНОВОЙ КИСЛОТЫ
}

\author{
Афиногенова А.Г. ${ }^{1,2}$, Ворошилова Т.М. ${ }^{3}$, Афиногенов Г.Е. ${ }^{2}$, Мадай Д.Ю. ${ }^{2}$, Спиридонова А.А. ${ }^{4}$ \\ ${ }^{1}$ ФБУН НИИ эпидемиологии и микробиологии имени Пастера, Санкт-Петербург, Россия \\ ${ }^{2}$ Санкт-Петербургский государственный университет, Санкт-Петербург, Россия \\ ${ }^{3}$ ФГБУ Всероссийский центр экстренной и радиационной медищины им. А.М. Никифорова МЧС России, \\ Санкт-Петербург, Россия \\ ${ }_{4}^{4}$ ФГБОУ ВО Первый Санкт-Петербургский государственный медицинский университет им. академика Павлова, \\ Санкт-Петербург, Россия
}

Резюме. В связи с возросшей частотой выделения изолятов грамотрицательных микроорганизмов, резистентных к карбапенемам, важным остается поиск способов усиления действия этого класса антибиотиков. Одним из возможных способов решения этой проблемы является комбинация карбапенемов с препаратами - ингибиторами металло-бета-лактамаз (МБЛ). К сожалению, в настоящее время разрешенных для применения в клинике ингибиторов МБЛ карбапенемрезистентных микроорганизмов. Патогенные микроорганизмы могут переживать антибиотическую атаку, проявлять свойства толерантности и персистенции, при этом инфекционный процесс продолжается. В связи с этим важно определение зависимости между бактерицидным действием антимикробных средств и временем экспозиции их воздействия на микроорганизм не в одной временной точке через 24 ч инкубации, а в нескольких - через 4, 8, 12 и 24 ч, так называемая кривая зависимости «время - летальное действие» (time-kill assay). Синергидный эффект двух препаратов отмечается при условии снижения уровня микробной популяции на $\geq 3 \log _{10}$. Для оценки эффективности синергидного действия карбапенемов и клодроновой кислоты использовали микрометод перекрестного титрования («шахматной доски») с последующим высевом содержимого ячеек на плотную питательную среду в разные временные промежутки. Исследования проводили в отношении клинического штамма Pseudomonas aeruginosa 532/14, выделенного от пациентов с инфекционными осложнениями, продуцирующего МБЛ генотипа VIM и характеризующегося высокой степенью резистентности к карбапенемам (МПК имипенама или меропенема 512 мкг/мл); микробная нагрузка $10^{6} \mathrm{KOE} / \mathrm{M}$. На ридере ELx800 проводили измерение оптической плотности при двух длинах волн (490 и 630 нм) при экспозициях от 4 до 24 ч и выявляли время появления логарифмической фазы роста тест-культуры. Следует отметить, что при бихроматическом измерении значение оптической плотности является разницей двух измерений, при этом значительно снижается погрешность результатов, вызванная царапинами или отпечатками пальцев на планшете. В исследовании показана способность клодроновой кислоты проявлять синергидный бактерицидный эффект с карбапенемами в отношении клинического резистентного штамма P. aeruginosa 532/14, продуцирующего металло-бета-лактамазу генотипа VIM. При этом в таком сочетании антимикробное действия у имипенема начинается с 8 часов инкубации до уровня $1,4 \log _{10}$ по сравнению с контролем, а с 12 ч отмечено полное подавление роста тест-культуры. При этом снижение роста тест-штамма составило $6 \log _{10}$. Меропенем в комбинации с клодроновой кислотой проявлял более выраженную активность: полное отсутствие роста $P$. aeruginosa 532/14 к 8 часам инкубации, подавление роста на $3,2 \log _{10}$. Этот показатель через 12-24 ч составил $6 \log _{10}$. Получение кривой зависимости «время - летальное действие» позволяет выявлять эффективные комбинации карбапенемов и ингибиторов металло-бета-лактамаз грамотрицательных бактерий, что имеет большое значение для повышения эффективности лечения тяжелых гнойно-септических осложнений у пациентов.

Ключевые слова: клодроновая кислота, карбапенемрезистентные грамотрицательные микроорганизмы, ингибитор металло-бета-лактамазы, карбапенемы, «time-kill assay».

\section{Introduction}

Due to the increased frequency of isolation of isolates of gram-negative microorganisms resistant to carbapenems, it is still important to find ways to enhance the action of this antibiotics class. One of the possible ways to solve this problem is combining carbapenems with agents that are metal-beta-lactamases (MBL) inhibitors. Unfortunately, at present no MBL inhibitors for carbapenem-resistant microorganisms are approved for clinical use [9]. Betalactam inhibitors are known and used in public health practice: tazobactam, sulbactam and clavulanic acid.
In addition, a number of chemical compounds are studied as inhibitors of beta-lactamases [11].

In the sphere of activities performed by microbiological laboratories, the determination of dependence between the bactericidal action of antibiotics and the time of exposure of a microbe to their effect (time-kill assay) is widely recognized. In general, it is a question of determining the bactericidal or fungicidal action of antibiotics or their combinations not at a single time point (usually after 24 hours), but in dynamics. Indications for the application of this technique relate mainly to in-depth studies of new antimicrobial agents or their properties, as well as 
to the effects of bacterial resistance that haven't been yet studied in everyday practice of microbiological laboratories (so-called "tolerance" of microorganisms, "persistence", "minor colonies", etc.) $[3,4,6]$.

Earlier, we showed the ability of etidronic acid (a medicinal agent from the group of bisphosphonates) to enhance the action of carbapenems on clinical strains of gram-negative bacteria that are resistant to carbapenems and produce MBL [1]. This study originated from the search for new MBL inhibitors for carbapenem-resistant microorganisms approved for clinical use and enhancing the action of carbapenems.

\section{Materials and Methods}

To assess the effectiveness of the synergistic action of carbapenems and clodronic acid, we used the cross-tapering micromethod (chessboard method) intended for testing the sensitivity of microorganisms to the combined effect of two antibiotics $[12,13]$, followed by inoculation of well contents onto Müller-Hinton solid medium. To study the dependence between the antimicrobic action of test articles combination with the time of exposure of a microorganism to their effect (time-kill assay), we determined the bactericidal activity of the mixture of medicinal agents not at a single time point after 24 hours of incubation, but at several time points: after $4,8,12$ and 24 hours of incubation.

The study used antibiotics (imipenem and meropenem) diluted during standard titration in MüllerHinton medium [5]. The initial clodronic acid concentrate for preparing an intravenous solution containing $60 \mathrm{mg} / \mathrm{ml}$ was diluted in Müller-Hinton medium by successive two-fold dilutions. $95 \mu$ of clodronic acid dilution were added to the wells of a polystyrene 96-well plate containing $95 \mu \mathrm{l}$ of the antibiotic dilution, so that the volume of the mixture made up $190 \mu \mathrm{l}$. We studied the Pseudomonas aeruginosa 532/14 clinical strain isolated in patients with infectious complications that produces MBL of the VIM genotype and is characterized by a high degree of resistance to carbapenems (MIC of imipenem and meropenem being $512 \mu \mathrm{g} / \mathrm{ml}$ ). The microbial burden was $10^{6} \mathrm{CFU} / \mathrm{ml} .10 \mu \mathrm{l}$ of microbial suspension were added to each well. Thus, the final microbial burden of the test strain in each well ran to $5 \times$ $10^{4} \mathrm{CFU}$ in $200 \mu \mathrm{l}$.

Table. Suppression of $P$. aeruginosa 532/14 growth over time in the presence of a combination of carbapenems with clodronic acid

\begin{tabular}{|c|c|c|c|c|c|}
\hline \multirow{2}{*}{ Test articles and their doses } & \multicolumn{5}{|c|}{$\begin{array}{l}\text { The CFU amount in } 1 \mu \mathrm{l} \text { of medium, when inoculated onto a solid growth medium } \\
\qquad(\mathrm{n}=5, \mathrm{P}<0.05)\end{array}$} \\
\hline & $\begin{array}{l}\text { before } \\
\text { incubation }\end{array}$ & $\begin{array}{l}4 \text { hours } \\
\text { of incubation }\end{array}$ & $\begin{array}{l}8 \text { hours } \\
\text { of incubation }\end{array}$ & $\begin{array}{l}12 \text { hours } \\
\text { of incubation }\end{array}$ & $\begin{array}{l}24 \text { hours } \\
\text { of incubation }\end{array}$ \\
\hline $\begin{array}{l}P \text {. aeruginosa } 532 / 14 \text { culture growth } \\
\text { control }\end{array}$ & $102 \pm 1.5$ & $116 \pm 0.9$ & $1.64 \times 10^{3} \pm 2.4$ & $\begin{array}{l}8.64 \times 10^{5} \pm \\
9.4 \times 10^{3}\end{array}$ & $\begin{array}{l}1.9 \times 10^{6} \pm \\
3.3 \times 10^{4}\end{array}$ \\
\hline Imipenem $1 / 2$ MIC & $101 \pm 2.3$ & $112 \pm 1.5$ & $1.56 \times 10^{3} \pm 8.8$ & $\begin{array}{l}7.8 \times 10^{5} \pm \\
5.7 \times 10^{3}\end{array}$ & $\begin{array}{l}1.1 \times 10^{6} \pm \\
3.3 \times 10^{4}\end{array}$ \\
\hline $\begin{array}{l}\text { Decrease in the CFU number in } \log _{10} \\
\text { relative to the control }\end{array}$ & - & - & - & - & - \\
\hline Clodronic acid $1 / 2$ MIC & $92 \pm 0.9$ & $96 \pm 1.2$ & $1.1 \times 10^{3} \pm 57.7$ & $\begin{array}{l}7.7 \times 10^{5 \pm} \\
8.8 \times 10^{3}\end{array}$ & $\begin{array}{l}1.26 \times 10^{6} \pm \\
1.2 \times 10^{4}\end{array}$ \\
\hline $\begin{array}{l}\text { Decrease in the CFU number in } \log _{10} \\
\text { relative to the control }\end{array}$ & - & - & - & - & - \\
\hline $\begin{array}{l}1 / 2 \text { MIC of imipenem }+1 / 2 \text { MIC } \\
\text { of clodronic acid }\end{array}$ & $87 \pm 8.8$ & $90 \pm 8.8$ & $60 \pm 8.8$ & 0 & 0 \\
\hline $\begin{array}{l}\text { Decrease in the CFU number in } \log _{10} \\
\text { relative to the control }\end{array}$ & - & - & 1.4 & 6 & 6.3 \\
\hline Meropenem $1 / 2$ MIC & $96 \pm 2.4$ & $105 \pm 2.8$ & $1.5 \times 10^{3} \pm 2.3$ & $\begin{array}{l}6.9 \times 10^{5} \pm \\
4.8 \times 10^{3}\end{array}$ & $\begin{array}{l}1.2 \times 10^{6} \pm \\
1.9 \times 10^{4}\end{array}$ \\
\hline $\begin{array}{l}\text { Decrease in the CFU number in } \log _{10} \\
\text { relative to the control }\end{array}$ & - & - & - & - & - \\
\hline Clodronic acid $1 / 2$ MIC & $92 \pm 2.1$ & $96 \pm 1.4$ & $1.4 \times 10^{3} \pm 2.4$ & $\begin{array}{l}6.8 \times 10^{5} \pm \\
5.1 \times 10^{3}\end{array}$ & $\begin{array}{l}1.4 \times 10^{6} \pm \\
2.1 \times 10^{4}\end{array}$ \\
\hline $\begin{array}{l}\text { Decrease in the CFU number in } \log _{10} \\
\text { relative to the control }\end{array}$ & - & - & - & - & - \\
\hline $\begin{array}{l}1 / 2 \text { MIC of meropenem }+1 / 2 \text { MIC } \\
\text { of clodronic acid }\end{array}$ & $100 \pm 2.2$ & $84 \pm 2.6$ & 0 & 0 & 0 \\
\hline $\begin{array}{l}\text { Decrease in the CFU number in } \log _{10} \\
\text { relative to the control }\end{array}$ & - & - & 3.2 & 6 & 6.3 \\
\hline
\end{tabular}


After every 4 hours of incubation, we performed inoculation out of wells with the test article concentration of $1 / 2$ MIC, as well as combinations of the corresponding carbapenem and clodronic acid in doses of $1 / 2$ MIC. During inoculation, $1 \mu 1$ of the respective well contents was introduced into $1 \mathrm{ml}$ of MüllerHinton medium and then $1 \mu \mathrm{l}$ was plated onto the surface of the Müller-Hinton agar and spread evenly with a spreader. Incubation took 24 hours at $37^{\circ} \mathrm{C}$.

Using the ELx800 reader (Bio-Tek Instruments Inc., USA), we measured the optical density at two wavelengths (490 and $630 \mathrm{~nm}$ ) at exposures from 4 to 24 hours and revealed the start time of the testing culture logarithmic growth phase. It should be noted that in bichromatic measurement, the optical density value is the difference between two measurements, which reduces significantly any possible errors in results caused by scratches or fingerprints on a plate.

The obtained results for 5 replications were subjected to statistical processing using Microsoft Excel 2007 and Statistica 6.0 by methods of parametric and nonparametric statistics.

\section{Results and Discussion}

Our preliminary studies based on the chessboard method defined both the intrinsic antimicrobic action of clodronic acid and its ability in sub-bactericidal concentration to increase the effect of carbapenems on the test strains of antibiotic-resistant gram-negative bacteria producing MBL. Then we modeled a system showing the ability of bisphosphonates to inhibit the activity of MBL and prevent an increase in the level of resistance to carbapenems in test strains of gram-negative microorganisms that were previously sensitive to them [2].

Table shows the results of inoculating the $P$. aeruginosa 532/14 clinical strain onto a solid growth medium at test time intervals. Literature data regis-

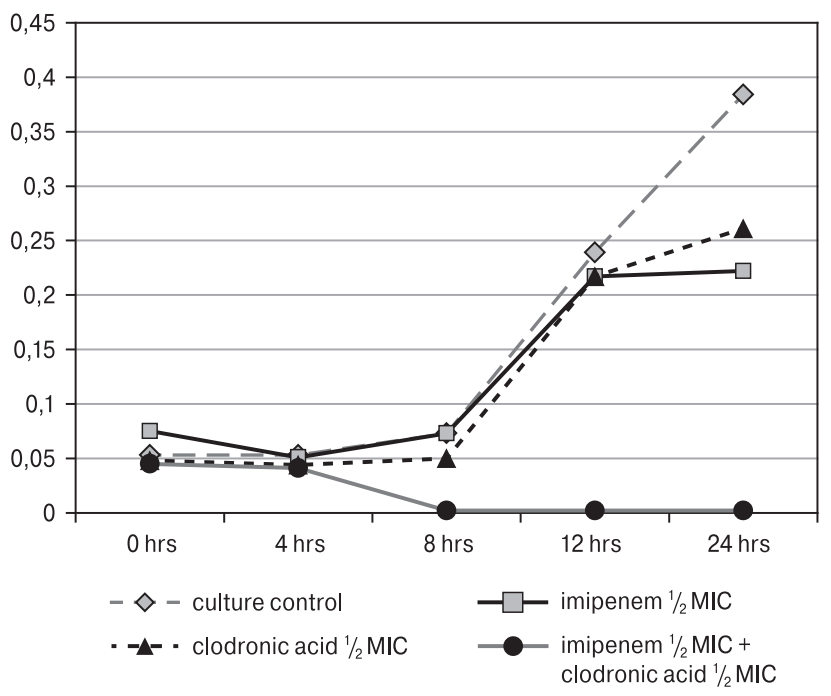

Figure 1. Phases of $P$. aeruginosa 532/14 growth in the presence of imipenem and clodronic acid ter the synergistic effect of two agents provided that the microbial population is reduced by $\geq 3 \log _{10}[8]$.

The data in Table indicate that the combined use of sub-bactericidal concentrations of carbapenems and clodronic acid as the MBL inhibitor has a "lethal effect" on the resistant $P$. aeruginosa 532/14 strain in the period from 8 to 24 hours. The reduction of the CFU number in the presence of a combination of imipenem and clodronic acid ran to $6 \log _{10}$ by $12-$ 24 hours of incubation. In the presence of a mixture of meropenem with clodronic acid, this effect was registered after 8 hours of incubation, when the test strain growth decreased by $3.3 \log _{10}$ in comparison with the control. These data indicate a synergistic bactericidal effect of the combinations used [10].

The determination of the time-kill assay for the combination of imipenem or meropenem with clodronic acid against $P$. aeruginosa 532/14 was based on the optical density of the substrate at various exposures. The data are presented in Fig. 1 and Fig. 2.

The logarithmic phase of the test strain growth in the control began after 4 hours of incubation. The culture growth curves in the presence of subbactericidal doses of the corresponding carbapenem or clodronic acid on both graphs run in parallel up to 12 hours. Then, the rate of $P$. aeruginosa 532/14 growth slowed by 24 hours. In the presence of a combination of sub-bactericidal concentrations of imipenem or meropenem with clodronic acid, the absence of a logarithmic growth phase of the test microorganism was observed.

When it comes to the matter of life and death of a patient with an infection caused by multiresistant microorganisms, it is important to determine the bactericidal action of combinations of antibiotics, rather than the bacteriostatic one, since the patient's weakened immunity does not complement the action of an antibiotic. Pathogenic microorganisms survive an antibiotic attack and show tolerance and persistence,

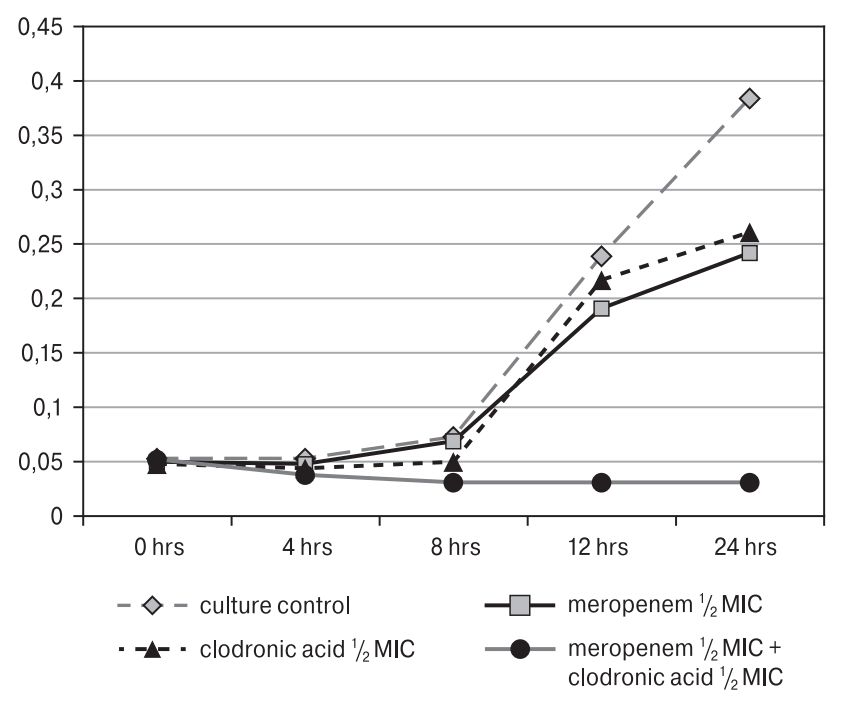

Figure 2. Phases of $P$. aeruginosa 532/14 growth in the presence of meropenem and clodronic acid 
while the infectious process continues. In this regard, it is important to determine the dependence between the bactericidal action of antimicrobial agents and the time of exposure of a microorganism to their effect (the so-called time-kill assay) [6].

Our preliminary studies based on the chessboard method have made it possible to identify promising MBL inhibitors for gram-negative bacteria from among the medicinal agents, i.e. bisphosphonates already approved for clinical use [1].

The present study shows the ability of clodronic acid to exhibit a synergistic bactericidal effect with carbapenems against a clinical resistant $P$. aeruginosa 532/14 strain producing MBL of the VIM genotype*. In this combination, the antimicrobic action of imi-

* Patent no. RU 2618433 has been obtained based on the research findings. penem starts after 8 hours of incubation up to $1.4 \log _{10}$ level as compared with the control. After 12 hours, the total suppression of testing culture growth is registered. The decrease in growth of the test strain ran to $6 \log _{10}$. Meropenem in combination with clodronic acid showed more pronounced activity, i. e. complete absence of $P$. aeruginosa 532/14 growth by 8 hours of incubation and suppression of growth by $3.2 \log _{10}$. In $12-24$ hours, this rate ran to $6 \log _{10}$.

The results of our study are consistent with foreign authors's methodical approach to the estimation of the synergistic effect of antimicrobial combinations [7, 8, $10,14]$. The derivation of the time-kill assay allows us to identify effective combinations of carbapenems and promising inhibitors of metal-beta-lactamases for gram-negative bacteria, which is of great importance for the increase in treatment efficacy for patients with severe purulent-septic complications.

\section{Список литературы/References}

1. Афиногенова А.Г., Ворошилова Т.М., Афиногенов Г.Е., Мадай Д.Ю. Оценка эффективности нового ингибитора металло-бета-лактамазы в условиях модельной системы in vitro // Инфекция и иммунитет. 2016. Т. 6, № 4. С. 335344. [Afinogenova A.G., Voroshilova T.M., Afinogenov G.E., Maday D.Y. The new metall-beta-lactamase's inhibitor efficacy in a model system in vitro. Infektsiya $i$ immunitet $=$ Russian Journal of Infection and Immunity, 2016, vol. 6, no. 4, pp. 335-344. doi: 10.15789/2220-7619-2016-4-335-344(In Russ.)]

2. Афиногенова А.Г., Ворошилова Т.М., Афиногенов Г.Е., Родионов Г.Г. «Метод шахматной доски» как тест для оценки снижения уровня резистентности грамотрицательных микроорганизмов к карбапенемам в присутствии бисфосфоната // Клиническая микробиология и антимикробная химиотерапия. 2015. T. 17, № 1. С. 24-32. [Afinogenova A.G., Voroshilova T.M., Afinogenov G.E., Rodionov G.G. «Checkerboard array» as a test for evaluation of decrease of microbial resistance decrease to capbapenems in the presence of bisphosphonate. Klinicheskaya mikrobiologiya i antimikrobnaya khimioterapiya $=$ Clinical Microbiology and Antimicrobial Chemotherapy, 2015, vol. 17, no. 1, pp. 24-32. (In Russ.)]

3. Борисова М.И., Лазакович Д.Н., Сидорова Н.А., Савушкин А.И. Биопленкообразующая активность и феномен персистенции микроорганизмов // Journal of Biomedical Technologies. 2015. № 2. C. 28-35. [Borisova M.I., Lazakovich D.N., Sidorova N.A., Savushkin A.I. Biofilm-forming activity and the phenomenon of persistense in microorganisms. Journal of Biomedical Technologies, 2015, no. 2, pp. 28-35. doi: 10.15393/j6.art.2015.3382(In Russ.)]

4. Бухарин О.В. Персистенция бактериальных патогенов как физиологический феномен // Вестник Московского Университета. Серия 16. Биология. 2008. № 1. С. 6-13. [Bukharin O.V. Persistence of bacterial pathogens as a physiological phenomenon. Vestnik Moskovskogo universiteta. Seriya 16. Biologiya = Herald of the Moscow State University. Series 16. Biology, 2008, no. 1, pp. 6-13. (In Russ.)]

5. Определение чувствительности микроорганизмов к антимикробным препаратам: методические указания. М.: Федеральный центр госсанэпиднадзора Минздрава России, 2004. 91 с. [Determination of the sensitivity of microorganisms to antimicrobial drugs: methodological guidelines. Moscow: Federal Center for State Sanitary and Epidemiological Supervision of the Russian Ministry of Health, 2004, 91 p.]. URL:http://fcgie.ru/download/elektronnaya_baza_metod_dokum/muk_1890-04.pdf (19.10.2018)]

6. Поляк М.С. Лабораторное обеспечение антибиотикотерапии. СПб.: ООО «Анатолия», 2012. 256 c. [Polyak M.S. Laboratornoe obespechenie antibiotikoterapii [Laboratory provision of antibiotic therapy]. SPb: LLC "Anatoliya”, 2012. 256 p.]

7. Aiyegoro O.A., Afolayan A.J., Okoh A.I. In vitro time kill assessment of crude methanol extract of Helichrysum pedunculatum leaves. African J. Biotechnol., 2008, vol. 7, no. 11, pp. 1684-1688. doi: 10.5897/AJB08.055

8. Basri D.F., Khairon R. Pharmacodynamic interaction of Quercus infectoria galls extract in combination with vancomycin against MRSA using microdilution checkerboard and time-kill assay. Evid. Based Complement. Alternat. Med., 2012, vol. 2012: 493156. doi: 10.1155/2012/493156

9. Bedenic B., Vraneš J., Sviben M., Beader N., Kalenić S. Postantibiotic and post-beta-lactamase inhibitor effect of carbapenems combined with EDTA against Pseudomonas aeruginosa strains producing VIM-metallo beta-lactamases. Chemotherapy, 2008, vol. 54, pp. 188-193. doi: 10.1159/000140461

10. Bhardwaj M., Singh B.R., Sinha D.K., Kumar V., Prasanna Vadhana O.R., Varan Singh S., Nirupama K.R., Pruthvishree and Archana Saraf B.S. Potential of herbal drug and antibiotic combination therapy: a new approach to treat multidrug resistant bacteria. Pharm. Anal. Acta, 2016, vol. 7, no. 11. doi: 10.4172/2153-2435.1000523

11. Drawz S.M., Bonomo R.A. Three decades of $\beta$-lactamase inhibitors. Clin. Microb. Rev., 2010, vol. 23, no. 1, pp. 160-201. doi: 10.1128/CMR.00037-09

12. Eliopoulos G.M., Moellering R.C. Antimicrobial combinations. In: Antibiotics in Laboratory Medicine; $4^{\text {th }}$ edition. Ed. V. Lorian. Baltimore, MD, USA: Williams \& Wilkins, 1996, pp. 330-396. 
13. Leber A. Synergism testing: broth microdilution checkerboard and broth macrodilution methods. In: Clinical Microbiology Procedures Handbook; 4 ${ }^{\text {th }}$ edition. Washington, DC: ASM Press, 2016, pp. 5.16.1-5.16.23. doi: 10.1128/9781555818814. $\operatorname{ch} 5.16$

14. Rani R., Sharma D., Chaturvedi M., Yadav J.P. Antibacterial activity of twenty different endophytic fungi isolated from Calotropis procera and time kill assay. Clin. Microbiol., 2017, vol. 6, no. 3. doi: 10.4172/2327-5073.1000280

\section{Авторы:}

Афиногенова А.Г., д.б.н., руководитель испытательного лабораторного центра ФБУН НИИ эпидемиологии и микробиологии имени Пастера; профессор кафедры челюстно-лицевой хирургии и хирургической стоматологии СПбГУ, Санкт-Петербург, Россия;

Ворошилова Т.М., врач-бактериолог, зав. лабораторией бактериологических исследований ФГБУ Всероссийского центра экстренной и радиационной медицины им. А.М. Никифорова МЧС России, Санкт-Петербург, Россия; Афиногенов Г.Е., д.м.н., профессор кафедры челюстнолицевой хирургии и хирургической стоматологии СПбГУ, Санкт-Петербург, Россия;

Мадай Д.Ю., д.м.н., профессор, зав. кафедрой челюстнолицевой хирургии и хирургической стоматологии СПбгу, Санкт-Петербург, Россия;

Спиридонова А.А., врач-бактериолог, зав. отделением клинической микробиологии ФГБОУ ВО Первый Санкт-

Петербургский государственный медицинский университет им. академика И.П. Павлова, Санкт-Петербург, Россия.

\section{Authors:}

Afinogenova A.G., PhD, MD (Biology), Head of Laboratory Testing Centre, St. Petersburg Pasteur Institute; Professor of Surgical Dentistry Department, St. Petersburg State University, St. Petersburg, Russian Federation;

Voroshilova T.M., Bacteriologist, Head of Bacterial Laboratory, The Nikiforov All-Russian Center of Emergency and Radiation Medicine, St. Petersburg, Russian Federation;

Afinogenov G.E., PhD, MD (Medicine), Professor of Surgical Dentistry Department, St. Petersburg State University,

St. Petersburg, Russian Federation;

Maday D.Yu., PhD, MD (Medicine), Professor, Head of Surgical Dentistry Department, St. Petersburg State University,

St. Petersburg, Russian Federation;

Spiridonova A.A., Head of Clinical Microbiology Department, Pavlov First St. Petersburg State Medical University, St. Petersburg, Russian Federation 